\title{
Food Labeling and Halal Mark
}

\section{Bashar H Malkawi*}

College of Law, University of Sharjah, Sharjah, United Arab Emirates

Over the years, there has been a controversy surrounding the use of "halal" as a designation on food products that meet Islamic dietary law. Halal symbols are certification trademarks of an organization and cannot be placed on a food label without that organization's permission [1]. The "halal" designation makes claims about ingredients of the food and the way food is processed. Consumers are assured that the product in question meets the Muslim slaughter rituals for animals.

Muslims consume food that is halal which literally means lawful or permitted. For meat to be halal, it cannot be of certain types of animals and must be butchered in a certain manner. Halal meat must be prepared according to the proper Islamic practice [2]. The Quran specifically allows certain types of meat such as cattle, camels, sheep, goat, seafood, and "that which you have taught birds and beasts of prey to catch, training them as God has taught you." In addition, animals that are not slaughtered in accordance with Islamic rules are forbidden. Some of the rules governing halal meat are somewhat similar to kosher practices [3].

The controversy arises when a state's food labeling regulations include labels that claim that certain types of food are prepared according to religious dietary restrictions. This issue is particularly controversial in countries where halal food cannot be easily found. For example, some states in the U.S. have enacted statutes that defined "kosher" and made it a crime to sell a product labeled as such if, in general, it was not processed in accordance with religious law [4]. Those statutes were ruled unconstitutional by courts and struck down ${ }^{1}$. Those statutes were considered to foster excessive state entanglement with religion ${ }^{2}$. Although the statues and court decisions in question apply to "kosher" food they have relevance as well to "halal" food under Islamic law. Several U.S. states adopted statutes that regulate the use of the term "halal" on food labels [5]. These statues may raise legal issues in the future and become the subjects of litigation and ultimately could be struck down.

Halal food is designed to protect Muslim consumers from fraud and mislabeling. Labeling prevent deception and help consumers make welfare-maximizing choices. A consumer can get the most only if he/ she has accurate information about the foods under consideration. Accordingly, the goal of label information is to help consumers identify the food products that best match their preferences, thus helping consumers spend wisely. The purpose of "halal" trademark is to prevent food from being illicitly passed off as halal.

\section{References}

1. Barry Newman (2006) Halal Meets Kosher in Health-Food Aisle. The Wall Street Journal, Newyork USA.

2. Rain LM (2001) Food Fights: Redefining the Current Boundaries of the Government's Positive Obligation to Provide Halal, Journal of Law \& Politics 17: 713-718.

3. Shayna MS (2004) Kosher Without Law: The Role of Nonlegal Sanctions in Overcoming Fraud within the Kosher Food Industry. Florida State University Law Review 31: 509-520.

4. Mark P (2010) The Constitutional Complexity of Kosher Food Laws. Columbia Journal of Law \& Social Problems.

5. Elijah LM (2006) Protecting Islam's Garden from the Wilderness: Halal Fraud Statutes and the First Amendment. Journal of Food Law \& Policy 2: 61-84.
*Corresponding author: Bashar H Malkawi, Associate Professor of Law, College of Law, University of Sharjah, Sharjah, United Arab Emirates, Tel: 0508281139; E-mail: bmalkawi@sharjah.ac.ae

Received December 30, 2013; Accepted December 30, 2013; Published January 06,2014

Citation: Malkawi BH (2014) Food Labeling and Halal Mark. Intel Prop Rights 2: e103. doi:10.4172/2375-4516.1000e103

Copyright: (c) 2014 Malkawi BH. This is an open-access article distributed under the terms of the Creative Commons Attribution License, which permits unrestricted use, distribution, and reproduction in any medium, provided the original author and source are credited. 